\title{
Morphological Characterization of Taro and Its Utilization as a Learning Resource of Biology Education in Eastern Indonesia
}

\author{
Anang Triyoso and Aprilia Baru \\ Universitas Pendidikan Muhammadiyah Sorong \\ atriyoso2@gmail.com
}

\begin{abstract}
The tendency to prioritize food crops, such as rice and wheat, to meet human needs has resulted in dependence, degradation, and loss of local knowledge. In this term, biology education plays its role by exploring the potential of local plants, including their use as learning resources. One of those local plants is the taro plant (Colocasia Esculenta L.), an alternative staple food for those who live in Eastern Indonesia. The research method used was qualitative research. The data collection techniques included observation, interviews, characterization, and questionnaires. The data collected were analyzed through descriptive analysis. The morphological characterization of taro was done based on Descriptors for Taro IPGRI (International Plant Genetic Resources Institute). The poster development procedure used was the ADDIE model. The results of the exploration showed five local taro accessions that had variations in morphological characters. The plant range was directly proportional to the plant height. There was one accession that was tall (AT 5) and had the potential to be cultivated on a large scale. Most of the leaves were green, while the leaf vein color was varying, namely white, green, and purple, with harvesting periods ranging between 4 to 9 months. The leaf vein pattern has a shape like a letter Y. Five accessions had petiole cross-sections, a waxy coating on the leaf surface, and predominantly white intervenii. The assessments of material experts, media, and users showed that the poster was feasible, usable as a biology learning resource.
\end{abstract}

\section{Keywords}

Characterization, Morphology, Taro, Biology Learning Resources

\section{Introduction}

Advances in science and technology have an impact on Biology learning resources. Theoretically, biology functions to connect humans with the world in which they live and shows its relationship with all forms of life. However, in reality, its learning resources adopt scientific phenomena which do not match the environment where humans live in. Several recent articles suggest that it is also part of social and economic problems worldwide (Ballard et al., 2017; Darling-Hammond et al., 2020; Fleischner et al., 2017; Turrini et al., 2018). The diverse biological contents sometimes do not match the student's backgrounds, because the cultural and geographical backgrounds that underlie the development of science are different.

The problem mentioned above has the potential to cause clashes in constructing students' knowledge. The findings showed that most textbooks are only suitable for low-to-intermediate levels of learning (Lau et al., 2018) to study the impact of changes that occur (Meineke et al., 2018). As much as $48 \%$ of teachers have identified local natural resources as learning media (Boleng \& Lumowa, 2019). The difficulty to find local potential to be used as biology learning resources was influenced by several factors such as learning time, teacher biology, and environmental conditions (Imtihana \& Djukri, 2021). The proportion of knowledge must be balanced to provide scientific rationality for natural phenomena faced by students in everyday life (Anazifa \& Hadi, 2017). The utilization of natural phenomena as learning resources can direct their learning process to be more contextual.

Therefore, providing learning resources based on real phenomena is very crucial in successful learning. Students, through biology, can learn about themselves and their surroundings (Karyadi et al., 2018; Usmeldi \& Amini, 2019). 
Utilizing local potential as a learning resource, students expectedly can obtain more accurate and accountable information (Slamet et al., 2019) to encourage a more contextual understanding and make them learners who understand it (learning how to learn).

Located in an area with a tropical climate, Indonesia is known as a country that has earned the nickname "Mega Biodiversity" for its best biodiversity in the world. However, in reality, with such abundant diversity, in fulfilling food sources, the population only prioritizes one type of plant, namely rice and wheat. Besides, the government still imports these foodstuffs, which continue to increase every year to meet the need for rice as a basic ingredient for various other processed food products (Alfons, 2007; Dewi et al., 2014). The tendency to prioritize food crops for meeting human needs, such as rice and wheat, has resulted in dependence, degradation, and loss of local knowledge. Biology education can take a role in overcoming these problems by increasing knowledge through exploring the potential of local plants and their use as learning resources. One of the plants is the taro plant (Colocasia Esculenta L.), which is an alternative staple food for the people of Eastern Indonesia, especially in Papua.

Taro is often cultivated in tropical areas with sufficient rainfall $(175-250 \mathrm{~cm} /$ year) and requires fertile soil in a humid environment with temperatures around $21-27^{\circ} \mathrm{C}$ (Andarini \& Risliawati, 2018; Minantyorini \& Hanarida, 2002). Taro tubers contain carbohydrates and protein reaching $13-19 \%$ and $1.4 \%$, respectively, as well as calcium, fat, iron, phosphorus, and B vitamins (Catherwood et al., 2007). Taro tubers are gluten-free, low in fat, and easy to digest because they have high enough fiber to facilitate digestive work (Hassan, 2014).

This research was done through field survey activities to record the morphological aspects of taro plants in the area. This characterization activity included exploration and identification activities to reveal the plant's excellence. The information obtained would be used as a reference to introduce the types of taros to a wider scope (Sunaryanti, 2012). Data on the morphological structure of plant parts is important, including the plant's shape and pattern development, external appearance, and various constituent organs. The data from this research on taro morphology characterization was expected to be a learning source of biology. Currently, learning resources are necessary to improve students' characters and their love in terms of local wisdom (Ramdiah et al., 2020). As a critical element of the learning system, such resources need to be developed continuously in learning activities.

\subsection{Objectives}

The aims of this study were to 1) determine the morphological characterization of taro (Colocasia esculenta L.) and its utilization and 2) describe the feasibility of learning resources in the form of a poster resulting from the study of taro characterization in Eastern Indonesia.

\section{Methods}

This research was divided into two stages. The former was qualitative descriptive to characterize the taro plant (Colocasia Esculenta L.), while the latter was research and development (R\&D) to develop the characterization results into learning resources in the form of a poster.

Colocasia Esculenta L. plants were characterized for their morphologies scientifically and without manipulation of circumstances and conditions. The research took place in Aifat Utara District, Papua Barat, from July to August 2021. The methods used were observation, interviews, characterization, documentation, and questionnaires. Morphological characterization of taro was carried out using Descriptors for Taro IPGRI (International Plant Genetic Resources Institute). The procedure for developing biology learning resources in the form of a poster was done used the ADDIE development model, covering five stages, namely Analysis, Design, Development, Implementation, and Evaluation (Molenda, 2003).

Research population means the generalization area of the subject with particular characteristics and qualities predetermined by the researcher in the study to draw the synthesis. The population of this study was the taro population in North Aifat District, Papua Barat. The sample was obtained according to information obtained from the initial survey from the local community and farmers. The sampling was done using the purposive sampling method, according to the research needs. The sample taken was then characterized for their morphologies.

Testing of learning resource products, in the form of a poster, resulting from taro morphology characterization based on local wisdom was analyzed based on data from questionnaires given to material expert lecturers, learning media expert lecturers, and Biology Education students at Universitas Pendidikan Muhammadiyah Sorong who had 
taken Plant Morphology course. The data analysis technique was descriptive analysis to process the data obtained from the results of the taro plant characterization, responses from validators and respondents, and poster assessment questionnaires.

\section{Results and Discussion (12 font)}

\subsection{Description of Location Geography (11 font)}

Aifat District, Maybrat Regency, is located in the western part of Papua Island. Geographically, this regency is located below the equator, between $01^{\circ} 00^{\prime}-02^{\circ} 30^{\prime}$ South Latitude and $131^{\circ} 00^{\prime}-133^{\circ} 00^{\prime}$ East Longitude and is located at an altitude of $0-1,362$ meters above sea level. It is bordered by Tambrauw and Manokwari Regencies (north), South Sorong Regency (south), Sorong Regency (west), Teluk Bintuni Regency (east). The total area is 5,461.69 km2, divided into twenty-four districts. The highest rainfall in 2020 was in September, which was $747 \mathrm{~mm}$. The maximum temperature in 2020 was 34 degrees Celsius, in March. The topography of the regency is relatively varied, consisting of some highlands (mountainous areas) and slopes, (inland $\pm 65 \%$ ), lowlands, beaches, and brackish water (35\%) (BPS, 2020).

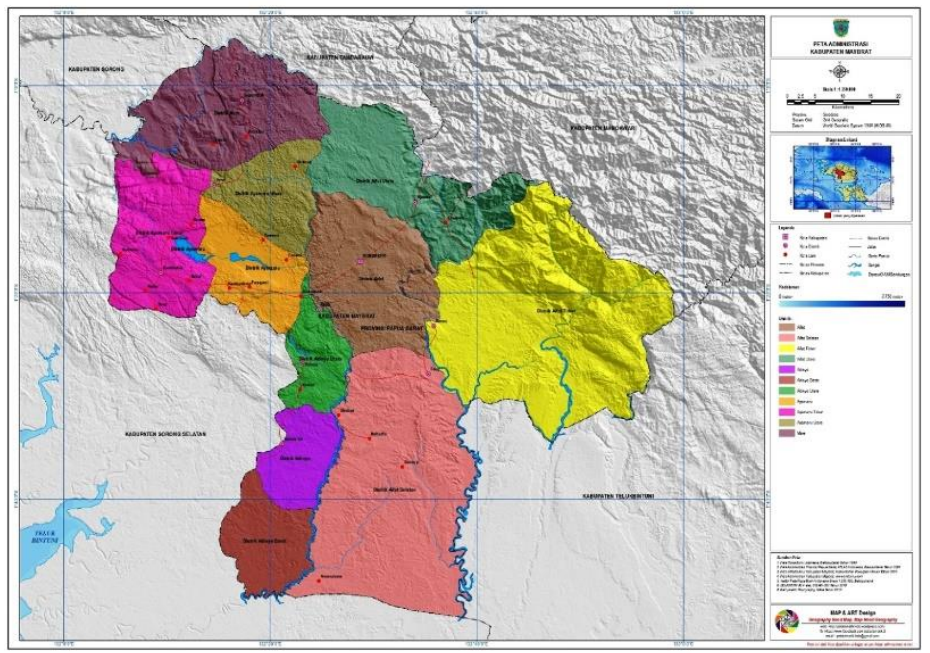

Figure 1. Location of Taro Morphological Observation

The distribution of taro plant accessions can be seen in Table 1 .

Table 1. General characteristics, area of origin, and harvesting period of five Maybrat local taro accessions

\begin{tabular}{ccccc}
\hline $\begin{array}{c}\text { No. of } \\
\text { accession }\end{array}$ & Local name & $\begin{array}{c}\text { Common } \\
\text { name/characteristics }\end{array}$ & Exploration location & $\begin{array}{c}\text { Harvesting period } \\
\text { (months) }\end{array}$ \\
\hline AT 1 & Awiah Monek & Green-trunked taro & Aifat District, Maybrat & $4-9$ \\
AT 2 & Awiah Martina & Green-trunked taro & Aifat District, Maybrat & $4-9$ \\
AT 3 & Awiah Rahel & Red-trunked taro & Aifat District, Maybrat & $4-9$ \\
AT 4 & Awiah Aksamina & Purple-trunked taro & Aifat District, Maybrat & $4-9$ \\
AT 5 & Awiah Kutawe & Purple-trunked taro & Aifat District, Maybrat & $4-9$ \\
\hline
\end{tabular}

The exploration found five accessions of taro with various morphological characteristics. The interviews with the community regarding the harvest period showed that all accessions are relatively the same. The farmers usually 
start harvesting taro after four months. Some of them do that after nine months. In general, the people of Papua know taro as keladi, but each region gives a different local name for taro. People around Aifat District, Maybrat, call taro awiah ati (AT 1, AT2, AT3, and AT4, where both names are the names of the person who first discovered it) and awiah kutawe. People sold taro in the market, in addition to using it for basic food needs.

\subsection{Plant Type Characterization}

The types of plants observed were those that were more than 4 months old and had entered the harvest period. Qualitative observations of the characterization of taro plant types are presented in Table 2.

Table 2. Characterization of Plant Types in Aifat District, Papua Barat

\begin{tabular}{cccccc}
\hline Accession & $\begin{array}{c}\text { Plant } \\
\text { range }\end{array}$ & Plant height & $\begin{array}{c}\text { Number } \\
\text { of } \\
\text { stolonc }\end{array}$ & $\begin{array}{c}\text { Stolon length } \\
(\mathbf{c m})\end{array}$ & $\begin{array}{c}\text { Number of } \\
\text { stokers }\end{array}$ \\
\hline AT 1 & medium & medium & 0 & 0 & 0 \\
AT 2 & medium & medium & 0 & 0 & 0 \\
AT 3 & medium & medium & 0 & 0 & 0 \\
AT 4 & medium & medium & 0 & 0 & 0 \\
AT 5 & medium & tall & 0 & 0 & 0
\end{tabular}

The results of the characterization of taro plants in Aifat District, Maybrat, as in Table 1 above, show that the plant range is directly proportional to plant height. Those sized medium were dominant, except for accession 1 , which was classified as tall (AT5). Other studies also stated that plant range is directly proportional to plant height (Gustian et al., 2017; Prabawa et al., 2021; Wulanningtyas et al., 2019). Tall plants (AT5) have the potential to be cultivated on a large scale.

\subsection{Leaf Morphological Characterization}

Morphological characterization of taro leaves is presented in Table 3.

Table 3. Leaf Morphological Characterization in Aifat District, Maybrat

\begin{tabular}{cccccc}
\hline Accession & $\begin{array}{c}\text { Leaf length } \\
(\mathrm{cm})\end{array}$ & $\begin{array}{c}\text { Leaf } \\
\text { width }(\mathrm{cm})\end{array}$ & $\begin{array}{c}\text { Leaf blade } \\
\text { color }\end{array}$ & $\begin{array}{c}\text { Leaf edge } \\
\text { color }\end{array}$ & $\begin{array}{c}\text { Wax } \\
\text { coating }\end{array}$ \\
\hline AU 1 & 27.6 & 15 & Green & Green & High \\
AU 2 & 27 & 12 & Dark Green & Green & High \\
AU 3 & 27 & 12 & Green & Green & High \\
AU 4 & 27.6 & 14 & Green & Green & High \\
AU 5 & 70.9 & 42.3 & Green & Green & High \\
\hline
\end{tabular}

The results of the leaf morphology characterization in Table 2 above show that the leaf color and leaf blade are predominantly green, indicating that the taro leaf color is generally green (Gustian et al., 2017; Prabawa et al., 2021; Wulanningtyas et al., 2019). All taro leaf accessions have a waxy coating.

Table 4. Junction color, main vein color, petiole color, midrib color, and midrib length in Aifat District, Maybrat

\begin{tabular}{ccccc}
\hline Accession & Junction color & Main vein color & Petiole color & $\begin{array}{c}\text { Midrib } \\
\text { color }\end{array}$ \\
\hline AU 1 & Green & Green & Green & Green \\
AU 2 & Purple & Green & Green & Green \\
AU 3 & Purple & White & White & Light green \\
AU 4 & Purple & Green & Green & Green
\end{tabular}


Proceedings of the International Conference on Industrial Engineering and Operations Management Monterrey, Mexico, November 3-5, 2021
AU 5
White
Green
White
Green

The petiole junctions obtained were green, purple, and white. The observations showed that the main colors of leaf veins were green and white. The observed midribs were green. The results of the characterization showed that all leaf veins form a Y pattern.

\subsection{Morphological Characterization of Tubers and Roots}

Table 5. Cormus length, cormus shape, cormus weight, intervenum color, skin surface, skin thickness, fiber level in Aifat District, Maybrat.

$\begin{array}{ccccc}\text { Accession Cormus Cormus shape } & \text { Cormus } & \text { Skin } & \text { Skin } & \text { Fiber level } \\ \text { length } & \text { weight } & \begin{array}{c}\text { Intervenum } \\ \text { color }\end{array} & \text { surface } & \text { thickness }\end{array}$

\begin{tabular}{lccccccc}
\hline AU 1 & 8 & Elliptical & .54 & White & Smooth & Thick & Low \\
AU 2 & 8 & Cylindrical & .36 & White & Smooth & Thick & Low \\
AU 3 & 8 & Cylindrical & .44 & White & Smooth & Thick & Low \\
AU 4 & 8 & Rounded & .43 & White & Smooth & Thick & Low \\
AU 5 & 12 & Elongated & .41 & White & $\begin{array}{c}\text { Stringy and } \\
\text { scaly }\end{array}$ & Thick & Low \\
\hline
\end{tabular}

Cormi have different lengths based on their shape. The longest cormus, found in accession AU5, was elongated and measured $12 \mathrm{~cm}$. The cormi shapes were cylindrical, elliptical, elongated, and rounded. The intervenii were predominantly white. The skin surfaces were generally smooth; scaly fibers were found only in the AU5 accession. Cormi had various skin thicknesses; in five accessions obtained, cormi with thin skin were present in 1 accession, while those with thick skin were in 4 accessions.

\subsection{Analysis of Biology Learning Resources in the form of a Poster}

The results of this study were in the form of a poster as additional learning resources in the Plant Morphology course. The poster was tested by material experts, media experts, and Biology Education students at Universitas Pendidikan Muhammadiyah Sorong. Testing was done through questionnaires.

The calculation of the questionnaire validated by the material experts resulted in the following data:

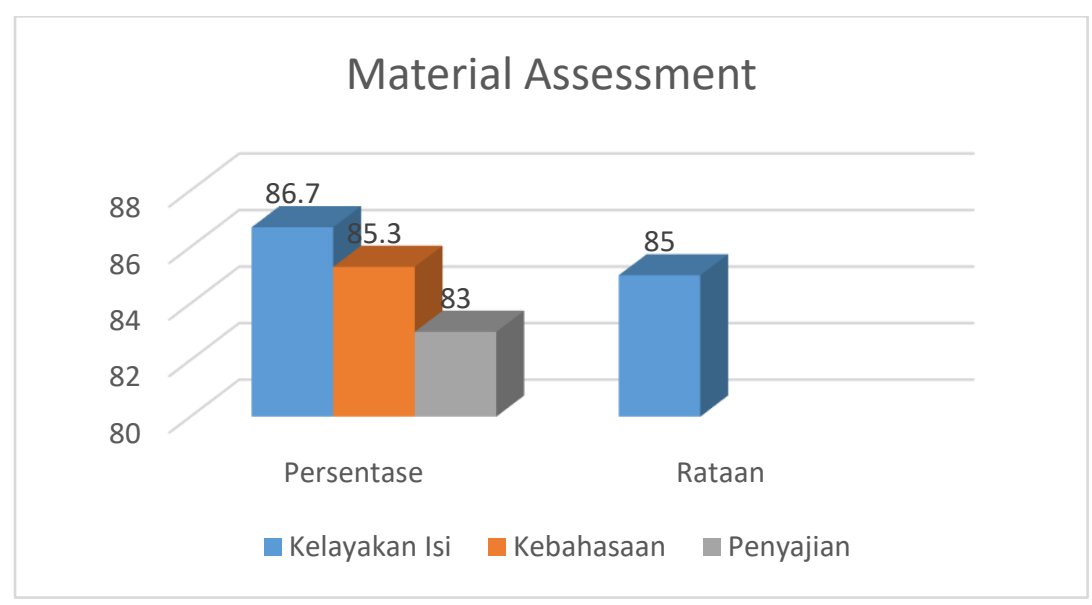

Figure 2. Poster Material Assessment

The results of the questionnaire assessment by material experts in the table show that the poster content, linguistics, and presentation got $86.7 \%, 85.3 \%$, and $83 \%$, respectively, indicating that all components were very good. The average percentage of all components of material assessment is $85 \%$, indicating that the poster was designed very 
well, thus feasibility and sufficient to be used as learning resources. The results of the questionnaire assessment by media experts obtained the following data:

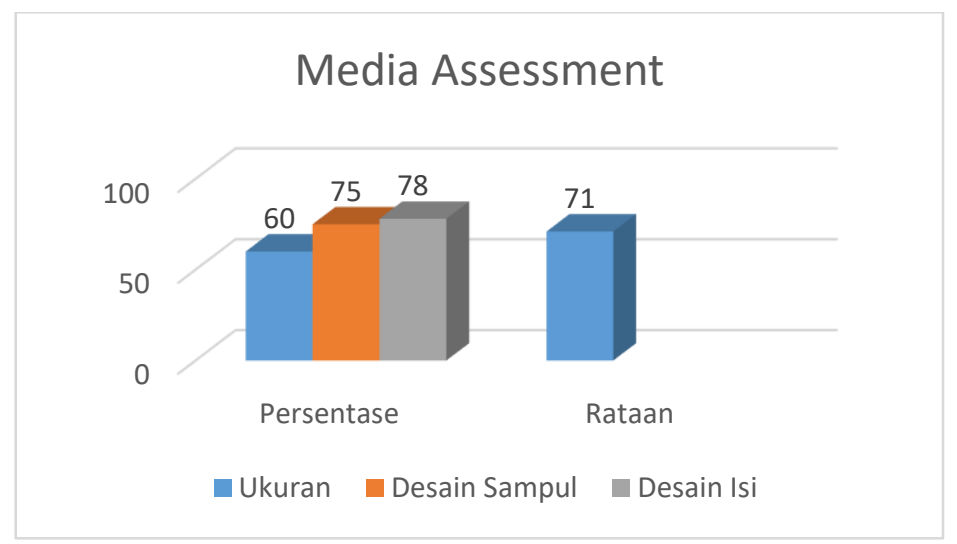

Figure 3. Poster Media Assesment

The results of the questionnaire calculation by media experts in the table show the feasibility of poster graphics was feasible with a percentage of $71 \%$. Poster size, cover design, and content design got $60 \%, 75 \%$, and $78 \%$, respectively. The questionnaire distributed to students obtained the following data:

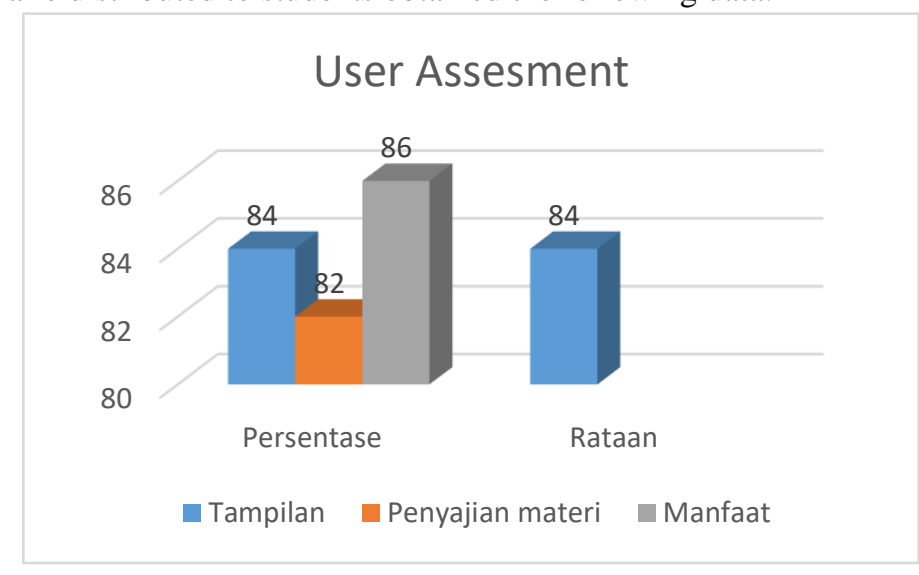

Figure 4. Poster Assessment by User

The results of the calculation of the questionnaire distributed to students in the table show that the poster display was very good with a percentage of $84 \%$, the presentation of the material was good with a percentage of $82 \%$, and the benefits were very good with a percentage of $86 \%$. On average, the percentage of all aspects of student assessment of the poster was $84 \%$. This value shows that the poster was very well-designed, according to students who were currently taking or who had taken Plant Morphology course.

\section{Conclusion}

The exploration results found five local taro accessions with varied morphological characteristics. Plant range was directly proportional to plant height. There was 1 accession that was tall (AT5) and had the potential to be cultivated on a large scale. The leaves were predominantly green, while the leaf veins were varying, namely white, green, and purple, with harvest periods ranging from 4 to 9 months. The leaf pattern was in the shape of the letter Y. Five accessions had petiole cross-sections and had a waxy coating on the leaf surface. The five accessions had a dominant white intervenii. The shapes of the cormi were cylindrical, elliptical, elongated, and rounded. The community, in addition to using taro to meet food needs, sold it in the market.

The poster resulting from the morphological characterization of taro (Colocasia esculenta L.) based on the assessment by material and media experts and users was declared feasible, thus usable as a biology learning resource. 
Proceedings of the International Conference on Industrial Engineering and Operations Management

Monterrey, Mexico, November 3-5, 2021

\section{References}

Alfons, J. B. (2007). Inovasi teknologi umbi-umbian mendukung ketahanan pangan. Seminar Nasional "Akselerasi Inovasi Teknologi Pertanian Spesifik Lokasi Mendukung Ketahanan Pangan Di Wilayah Kepulauan," 175-188.

Anazifa, \& Hadi. (2017). The Integration of Javanese Indigenous Knowledge in Biology Learning Resources Development. Journal of Physics: Conference Series, 812(1). https://doi.org/10.1088/1742-6596/755/1/011001

Andarini, Y. N., \& Risliawati, A. (2018). Variabilitas karakter morfologi plasma nutfah talas (Colocasia esculenta) lokal Pulau Jawa. Buletin Plasma Nutfah, 24(1), 63-76.

Ballard, H. L. ... Harris, E. M. (2017). Youth-focused citizen science: Examining the role of environmental science learning and agency for conservation. Biological Conservation, 208, 65-75. https://doi.org/10.1016/j.biocon.2016.05.024

Boleng, D. T., \& Lumowa, S. V. T. (2019). Responses of biology teachers of senior high school about utilization the local natural resources as learning media at Samarinda city. AIP Conference Proceedings, 2120, 1-5. https://doi.org/10.1063/1.5115701

Catherwood, D. J. ... Douglas, J. A. (2007). Oxalate content of cormels of Japanese taro (Colocasia esculenta (L.) Schott) and the effect of cooking. Journal of Food Composition and Analysis, 20(3-4), 147-151. https://doi.org/10.1016/j.jfca.2005.12.012

Darling-Hammond, L. ... Osher, D. (2020). Implications for educational practice of the science of learning and development. Applied Developmental Science, 24(2), 97-140. https://doi.org/10.1080/10888691.2018.1537791

Dewi, O. R. ... Anggarwulan, E. (2014). Pertumbuhan dan struktur anatomi daun dua varietas ganyong (Canna edulis) pada ketersediaan air berbeda. Bioteknologi, 11(1), 5-10. https://doi.org/10.13057/biotek/c110102

Fleischner, T. L. ... Zander, L. (2017). Teaching Biology in the Field: Importance, Challenges, and Solutions. BioScience, 67(6), 558-567. https://doi.org/10.1093/biosci/bix036

Gustian ... Rinaldo, R. (2017). Karakterisasi Morfologi Tanaman Talas di Kecamatan Sipora Selatan, Kabupaten Kepulauan Mentawai,Sumatera Barat. Prosiding, 1, 159-168.

Hassan, Z. H. (2014). Aneka Tepung Berbasis Bahan Baku Lokal Sebagai Sumber Pangan Fungsional Dalam Upaya Meningkatkan Nilai Tambah Produk Pangan Lokal. Pangan, 23(1), 93-107.

Imtihana, \& Djukri. (2021). Analysis Learning Resources Based Local Potential of Pacitan Regency as Biology Learning in Senior High School. Proceedings of the 7th International Conference on Research, Implementation, and Education of Mathematics and Sciences (ICRIEMS 2020), 528(Icriems 2020), 129-135. https://doi.org/10.2991/assehr.k.210305.020

IPGRI. (1999). Descriptors for Taro (Colocasia esculenta). In Edible Medicinal and Non Medicinal Plants. International Plant Genetic Resources Institute. https://doi.org/10.1007/978-94-017-9511-1_13

Karyadi, B. ... Enersi, D. (2018). The development of learning model for natural science based on environmental in conservation area of Bengkulu University. Journal of Physics: Conference Series, 1013(1). https://doi.org/10.1088/1742-6596/1013/1/012074

Lau, K. H. ... Thomas, S. (2018). The role of textbook learning resources in e-learning: A taxonomic study. Computers and Education, 118, 10-24. https://doi.org/10.1016/j.compedu.2017.11.005

Meineke, E. K. ... Davies, T. J. (2018). The unrealized potential of herbaria for global change biology. Ecological Monographs, 88(4), 505-525. https://doi.org/10.1002/ecm.1307

Minantyorini, \& Hanarida, I. (2002). Panduan karakterisasi dan evaluasi plasma nutfah talas. Komisi Nasional Plasma Nutfah.

Molenda, M. (2003). In search of the elusive ADDIE model. Performance Improvement, 42(5), 34-37. https://doi.org/10.2307/2073804

Prabawa, P. S. ... Sudirga, I. G. M. (2021). EKSPLORASI DAN KARAKTERISASI MORFOLOGI SUMBER DAYA GENETIK TALAS ( Colocasia esculenta L .) DI KABUPATEN BULELENG EXPLORATION AND MORPHOLOGICAL CHARACTERIZATION OF TARO ( Colocasia esculenta L .) GENETIC RESOURCES IN BULELENG REGENCY. Jurnal Pertanian Agros, 23(1), 61-73.

Ramdiah, S. ... Fauzi, A. (2020). South Kalimantan local wisdom-based biology learning model. European Journal of Educational Research, 9(2), 639-653. https://doi.org/10.12973/eu-jer.9.2.639

Slamet, A. ... Hudha, A. M. (2019). Developing genetic learning module based on blue eyes phenomenon in Buton Island, Southeast Sulawesi. Jurnal Pendidikan Biologi Indonesia, 5(1), 69-76. https://doi.org/10.22219/jpbi.v5i1.7071

Sunaryanti, D. P. (2012). Analisis Keanekaragaman Tanaman Kana (Canna sp.) Berdasarkan Karakter Morfologi.

Turrini, T. ... Bonn, A. (2018). The threefold potential of environmental citizen science - Generating knowledge, 
creating learning opportunities and enabling civic participation. Biological Conservation, 225(July), 176-186. https://doi.org/10.1016/j.biocon.2018.03.024

Usmeldi, U., \& Amini, R. (2019). The effect of integrated learning model to the students competency on the natural science. Journal of Physics: Conference Series, 1157(2). https://doi.org/10.1088/1742-6596/1157/2/022022

Wulanningtyas, H. S. ... Baliadi, Y. (2019). Keragaman Morfologi Talas (Colocasia esculenta L.) Lokal Papua (Variability on Morphological Characters the Papuan Locally Taro [Colocasia esculenta L.]). Buletin Plasma Nutfah, 25(49), 23-30.

\section{Biography (12 font)}

Anang Triyoso adalah pengajar dan peneliti di Universitas Pendidikan Muhammadiyah Sorong. Beliau menyelesaikan studi pendidikan sarjana di Universitas Cenderawasih pada tahun 2000 dan Magister Pendidikan Sains di Universitas Negeri Surabaya pada tahun 2013. Saat ini menjadi editor in chief di Jurnal Pendidikan pada tahun 2013 hingga sekarang.

Aprilia Baru adalah mahasiswa Program Studi Pendidikan Biologi FKIP Universitas Pendidikan Muhammadiyah Sorong. Beliau adalah salah satu putra asli Papua asal Maybrat yang terlibat dalam penelitian bersama dosen. 